\title{
PELATIHAN SHOLAT JAMAK DAN QASHAR BAGI ANGGOTA MAJELIS TAKLIM RUMPUAN AN NISA' KOTA BENGKULU SESUAI TUNTUNAN RASULULLAH SAW
}

\author{
Dedy Novriadi ${ }^{(1)}$ Desi Firmasari $^{(2)}$ Siti Misbah $^{(3)}$ \\ ${ }^{1,2,3)}$ Fakultas Agama Islam, Universitas Muhammadiyah Bengkulu \\ Email : Dedynovriadi@umb.ac.id
}

\begin{abstract}
ABSTRAK
Menjamak sholat adalah menghimpun (mengumpulkan) dua sholat yang dikerjakan dalam satu waktu sedangkan Mengqashar sholat adalah memendekkan jumlah raka'at shalat dari empat raka'at menjadi dua raka'at. Permasalahan di Majelis Taklim Rumpun An Nisa' Kota Bengkulu bahwa masih banyak anggota pengajian yang belum memahami dalil dan bagaimana tata cara pelaksanaan sholat Jamak dan Qashar, Hal ini disebabkan karena mereka beralasan karena sholat jamak dan qashar jarang dilaksanakan dan ada ketentuannya tersendiri.Metode pelaksanaan yang dilakukan adalah Pelatihan serta demontrasi. Sosialiasasi dan pelatihan serta demontrasi yaitu memberikan penyuluhan dan demontrasi kepada Anggota Majelis Taklim Rumpun An Nisa' Kota Bengkulu. Berdasarkan dari hasil pelatihan sholat Jamak dan Qashar bagi Anggota Majelis Taklim Rumpun An Nisa' Kota Bengkulu, ternyata 95\% anggota majelis taklim sudah mengetahui dan memahami dalil dan tata cara melaksanakan sholat Jamak dan Qashar sesuai dengan tuntunan Rasulullah SAW dan 5\% anggota majelis taklim sudah mengetahui tata caranya tetapi belum memahami dalilnya.
\end{abstract}

\section{Kata Kunci: Sholat Jamak dan Qashar, Tuntunan Rasulullah SAW}

\section{PENDAHULUAN}

\subsection{Analisis Situasi}

Shalat merupakan salah satu Ibadah Mahdhah yang perlu mendapat perhatian penting, karena ibadah ini tidak boleh dikerjakan atau dilaksanakan /diamalkan sesuka hati kita, melainkan harus didasarkan petunjuk yang jelas dari Rasulullah saw. Dalam melaksanakan ibadah shalat, harus bersandarkan pada tuntunan Rasulullah SAW, sebagaimana sabdanya:

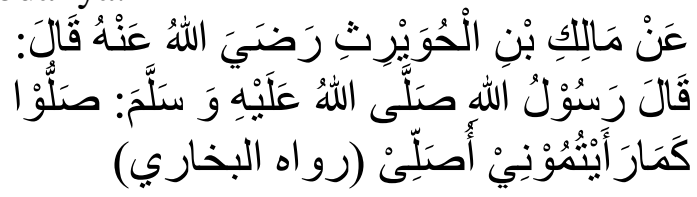

Dari Malik bin Huwairis r.a. bahwa Rasulullah saw. bersabda: "Shalatlah kalian sebagaimana kalian melihat aku mengerjakan shalat. (HR. Bukhari).
Dalam Islam sholat mempunyai arti penting dan kedudukan yang sangat istimewa dan Islam juga yang mewajibkan shalat 5 (lima) waktu yang biasa kita sebut sebagai shalat fardhu. Adapun Shalat fardhu antara lain adalah; shalat subuh, zuhur, asar, maghrib dan isya'. Hukum shalat fardhu adalah fardhu ain (kewajiban bagi setiap orang Muslim, yang apabila ditinggalkan berdosa).

Menjamak dan mengqashar sholat termasuk rukhshah (keringan atau kemurahan) yang diberikan Allah SWT kepada hambanya karena adanya kondisi yang menyulitkan apabila sholat dilakukan dalam keadaan biasa. Menjamak sholat adalah menghimpun (mengumpulkan) dua sholat yang dikerjakan dalam satu waktu sedangkan Mengqashar sholat adalah memendekkan jumlah raka'at shalat dari empat raka'at menjadi dua raka'at. 
1). Sholat Jamak Qashar Taqdim

$\checkmark$ Sholat zuhur dua raka'at dan sholat ashar dua raka'at dikerjakan pada waktu sholat zuhur.

$\checkmark$ Sholat Magrib tiga raka'at dan sholat isya dua raka'at dikerjakan pada waktu sholat magrib.

2). Jamak Qashar Takhir.

$\checkmark$ Sholat zuhur dua raka'at dan sholat ashar dua raka'at dikerjakan pada waktu sholat ashar.

$\checkmark$ Sholat Magrib tiga raka'at dan sholat isya dua raka'at dikerjakan pada waktu sholat isya.

Sebab-sebab diperbolehkannya mengerjakan sholat jama' adalah:

a. Karena berada di Arafah dan Muzdalifah (Ketika Haji)

b. Karena dalam Safar (Berpergian)

c. Karena Hujan Deras

d. Karena Sakit atau Uzur.

Berdasarkan informasi dari Ketua Majelis Taklim Rumpun An Nisa' Kota Bengkulu bahwa masih banyak anggota pengajian yang belum memahami bagaimana tata cara pelaksanaan sholat Jamak dan Qashar, Hal ini disebabkan karena mereka beralasan karena sholat jamak dan qashar jarang dilaksanakan dan ada ketentuannya tersendiri.

\subsection{Permasalahan Mitra}

Beradasarkan analisis situasi dilingkungan mitra dapat diuraikan beberapa permasalahan yang dihadapi oleh mitra adalah masih rendahnya pengetahuan anggota majelis taklim tentang ketentuan dan kapan pelaksanaan serta tata cara sholat jamak dan qashar.

\section{TARGET DAN LUARAN}

\subsection{Target}

Target dari kegiatan pengabdian ini sesuai dengan rencana kegiatan adalah :

Masyarakat di Lingkungan Majelis Taklim Rumpun An Nisa' Kota Bengkulu terutama Ibu-ibu anggota Majelis Taklim Rumpun An Nisa' mengetahui tata cara sholat Jama' sesuai dengan tuntunan Rasulullah SAW.

\subsection{Luaran}

Dengan adanya kegiatan pengabdian pada Anggota Majelis Taklim Rumpun An Nisa' Kota Bengkulu, diharapkan dapat diperoleh luaran sebagai berikut :

a. Anggota Majelis Taklim Rumpun An Nisa' memahami dalil-dalil tentang Sholat Jamak dan Qashar sesuai tuntunan Rasulullah saw.

b. Anggota Majelis Taklim Rumpun An Nisa' lebih mandiri dan menguasai tata cara Sholat Jamak dan Qashar.

\section{METODE PELAKSANAAN}

\subsection{Metode Pelaksanaan}

Program pelatihan yang disusun ini merupakan bidang pengabdian pada masyarakat, oleh karena itu metode pelaksanaan yang dilakukan adalah Pelatihan dan demontrasi yaitu memberikan Penyuluhan dan demontrasi kepada anggota majelis taklim Rumpun An Nisa' Kota Bengkulu.

\subsection{Pelaksanaan Kegiatan}

Kegiatan pengabdian masyarakat ini dilakukan dengan beberapa metode yaitu pelatihan dan demontrasi kepada anggota Majelis Taklim Rumpun An Nisa' Kota Bengkulu.

\section{HASIL DAN PEMBAHASAN \\ 4.1 Hasil}

Berdasarkan dari hasil pelatihan Tata cara sholat Jamak dan Qashar bagi anggota Majelis Taklim Rumpun An Nisa' Kota Bengkulu sesuai tuntunan Rasulullah saw, ternyata anggota majelis taklim sudah mengetahui dalil dan tata cara mengerjakan sholat jamak dan Qashar sesuai dengan tuntunan Rasulullah SAW.

\subsection{Pembahasan}

\section{Kegiatan Pelatihan dan Demontrasi} Sholat Jamak dan Qashar

4.1 Dalil Sholat Jamak dan Qashar. a. Pengertian Sholat Jamak dan Qashar

Menjamak sholat adalah menghimpun (mengumpulkan) dua sholat yang dikerjakan dalam satu waktu. Adapun sholat yang dapat dijamak adalah sholat 
zuhur dengan sholat ashar dan sholat magrib dengan sholat isya.

Menjamak dan mengqashar sholat termasuk rukhshah(kemurahan/keringan yang berikan Allah kepada hambanya karena adanya kondisi yang menyulitkan bila shalat dilakukan dalam keadaan biasa.(Syakir Jamaluddin, 2010).

Dilihat dari segi pelaksanaannya sholat jamak terbagi dua macam yaitu:

1). Jamak Taqdim; menghimpun dua sholat yang dikerjakan pada waktu sholat yang pertama;

$\checkmark$ Sholat zuhur dan sholat ashar dikerjakan pada waktu sholat zuhur.

$\checkmark$ Sholat Magrib dan sholat isya dikerjakan pada waktu sholat magrib.

2). Jamak Takhir; menghimpun dua sholat yang dikerjakan pada waktu sholat yang kedua(terakhir);

$\checkmark$ Sholat zuhur dan sholat ashar dikerjakan pada waktu sholat ashar.

$\checkmark$ Sholat Magrib dan sholat isya dikerjakan pada waktu sholat isya.

Qashar adalah memendekkan (meringkas), adapun sholat jamak qashar adalah meringkas jumlah sholat raka'at sholat yang empat raka'at menjadi dua raka'at. Adapun sholat fardu yang dapat diqashar adalah sholat zuhur, sholat ashar, sholat magrib dan sholat isya sedangkan sholat subuh jumlahnya tetap dua raka'at tidak dapat diringkas.

1). Sholat Jamak Qashar Taqdim

$\checkmark$ Sholat zuhur dua raka'at dan sholat ashar dua raka'at dikerjakan pada waktu sholat zuhur.

$\checkmark$ Sholat Magrib tiga raka'at dan sholat isya dua raka'at dikerjakan pada waktu sholat magrib.
2). Jamak Qashar Takhir.

$\checkmark$ Sholat zuhur dua raka'at dan sholat ashar dua raka'at dikerjakan pada waktu sholat ashar.

$\checkmark$ Sholat Magrib tiga raka'at dan sholat isya dua raka'at dikerjakan pada waktu sholat isya.

\section{c. Dasar hukum Sholat Jamak dan Qashar}

Rasulullah saw bersabda:

عَنْ أَنَسِ بْنِ مَالَلِكِ رَضِيَ اللهُ عَنْهُ قَالَ كَانَ

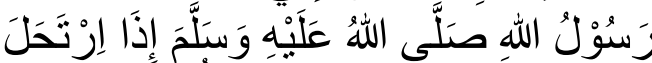

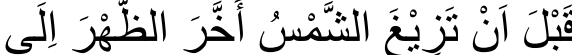

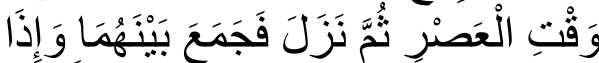

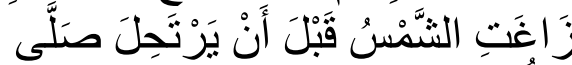

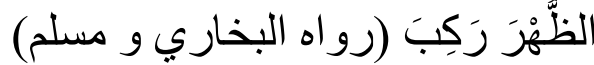

Dari Anas bin Malik r.a berkata: Rasulullah saw, setiap berangkat berpergian sebelum tergelincir matahari, biasanya, beliau mengakhirkan shalat zuhur pada waktu ashar, kemudian beliau turun (berhenti) guna menjama'kan keduanya. Dan bila telah tergelincir matahari sebelum beliau berangkat, beliau shalat zuhur dulu baru naik kendaraan." (HR.Bukhary \& Muslim) (Compact Disc (CD).1999. Al Maktabah al-Syamilah)

Rasulullah saw bersabda:

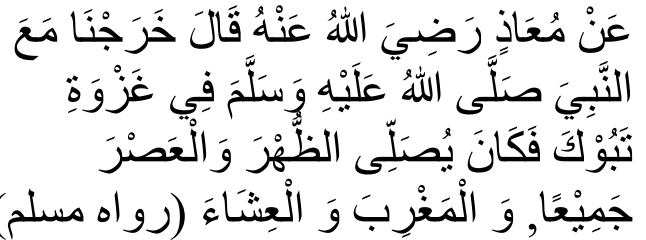

Dari Mu'az r.a berkata: Kami keluar bersama Nabi saw, pada waktu terjadi perang Tabuk.Ketika itu beliau mengerjakan shalat zuhur dan Ashar dengan jama'. Magrib dan Isya'pun dengan jama'(HR.Muslim)

QS. An Nisa' ayat 101

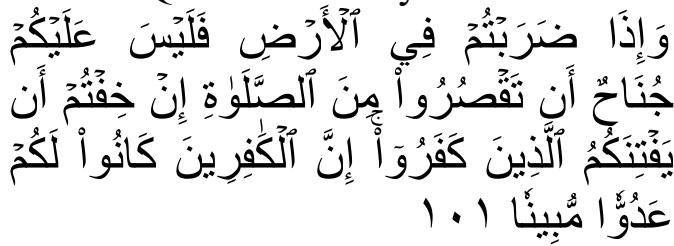




\section{Ourralsm}

Dan apabila kamu berpergian di muka bumi, maka tidaklah mengapa kamu mengqashar shalatmu.Jika kamu takut diserang oleh orangorangkafir.Sesungguhnya orang-orang kafir itu adalah musuh yang nyata bagimu.(QS.An Nisa' :101) (Departemen Agama RI, 1982)

Rasulullah saw bersabda:

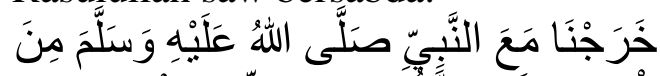

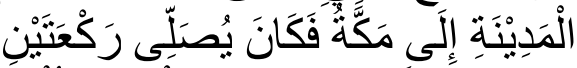

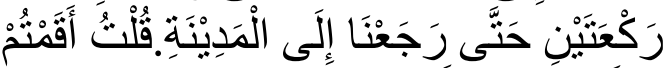

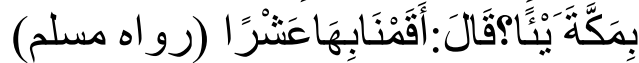

Kami keluar bersama Nabi saw dari Madinah ke Makkah, beliau sholat dua raka'at-dua raka'at hingga kami kembali ke Madinah.Aku (yakni Yahya) bertanya: Apakah kalian tingal di Makkah sebentar? Dia(anas) menjawab: kami tinggal di Makkah 10 hari. (HR.Bukhari dan Muslim)

\subsection{Tata Cara Mengerjakan Sholat Jamak dan Qashar}

Sholat Jamak Qashar bisa dilaksanakan secara munfarid (Sendiri) dan berjama'ah. Secara umum tidak ada perbedaan tata cara mengerjakan sholat jamak qashar dengan sholat lainnya, tetapi yang membedakan adalah niat sholat jamak qashar taqdim atau takhir dan diantara dua sholat diselingi dengan iqomah

Adapun tata cara mengerjakan sholat jamak Qashar Taqdim dan Sholat Jamak Qashar Takhir adalah :

a. Niat Sholat Jamak Qashar Taqdim atau Sholat Jamak Qashar Takhir

Hadist dari Umar bin Khattab:

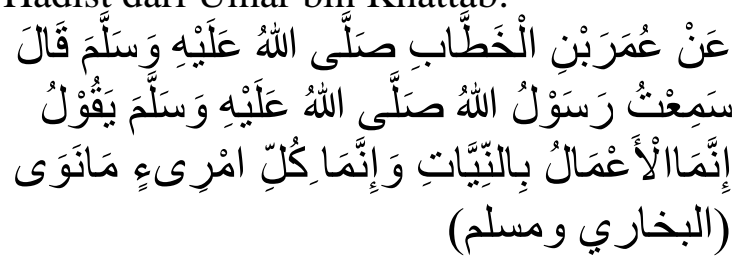

Diriwayatkan dari Umar bin

Khattab r.a. ia berkata: saya mendengar Rasulullah saw bersabda: Sesungguhnya (amal) itu adalah harus dengan niat dan pahala bagi setiap orang hanya tergantung pada niatnya.... (HR.Bukhary dan Muslim).
(Compact Disc (CD).1999. Al Maktabah al-Syamilah)

b. Berdiri

Berdiri sempurna menghadap ke arah kiblat. Hal ini dipahami dari firman

Allah SWT:

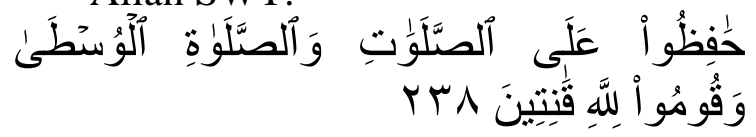

Peliharalah semua shalat(mu), dan (peliharalah) shalat wusthaa (yakni shalat 'Ashar). Berdirilah karena Allah (dalam shalatmu) dengan khusyu'.(QS.Al Baqarah:238). (Departemen Agama RI, 1982)

Sabda Rasulullah saw :

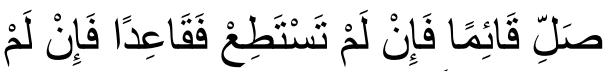

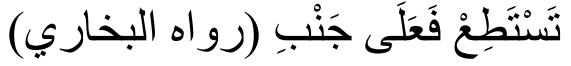

Shalatlah dengan berdiri, jika tidak kuat maka duduklah, dan manakala tidak kuat maka dengan cara berbaring (H.R. Bukhari).

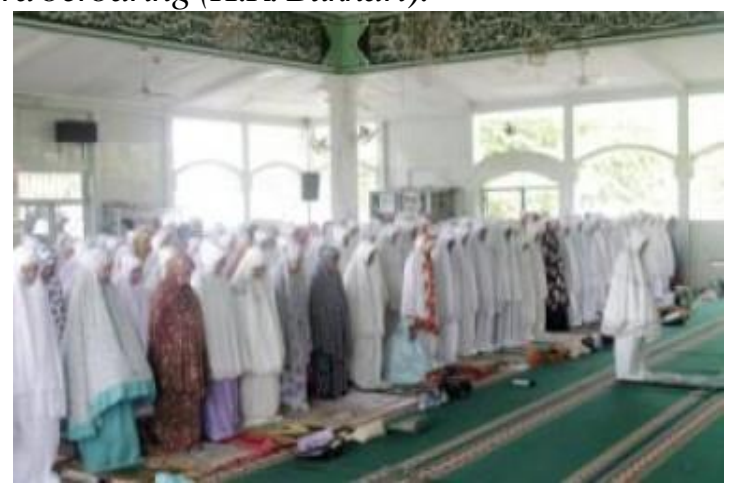

Gambar 1 Praktek Sholat Jamak dan Qashar

c. Membaca Takbiratul Ihram

Mengangkat kedua tangan sejajar dengan telinga dan bahu sekaligus, sambil bertakbir: Allahu Akbar. Sabda Rasulullah saw:

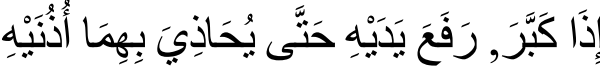

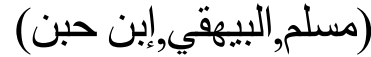

Apabila bertakbir, beliau mengangkat kedua tangannya hingga keduanya sejajar dengan kedua telinga.(HR.Muslim,Al Baihaqi dan Ibnu Hibban).

d. Kemudian membaca salah satu do'a iftitah (Majelis Tarjih Pimpinan Pusat Muhammadiyah, 2014 )sebagai berikut: Menurut hadist Abu Hurairah : 


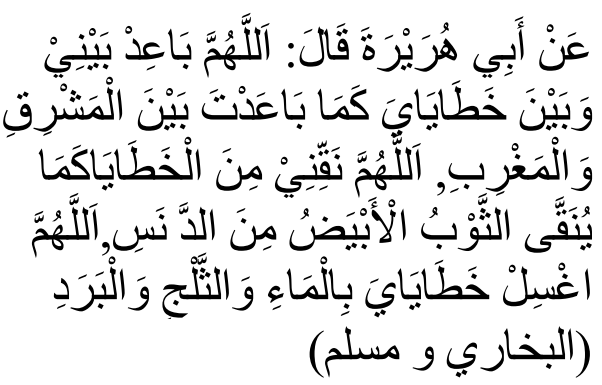

Menurut hadits Ali bin Abi Thalib:

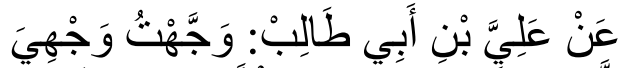

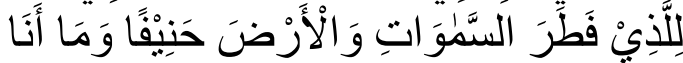

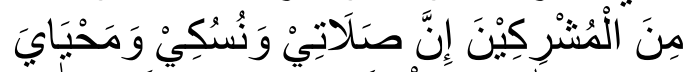

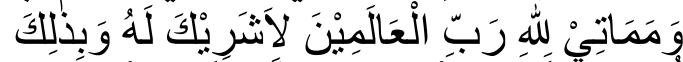

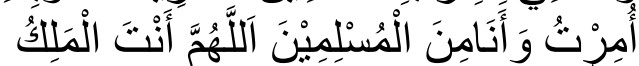

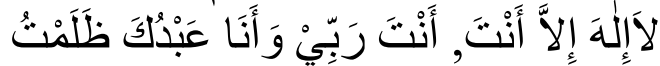

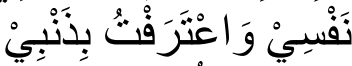

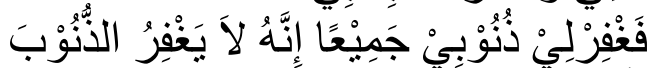

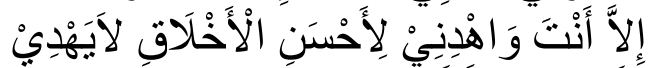

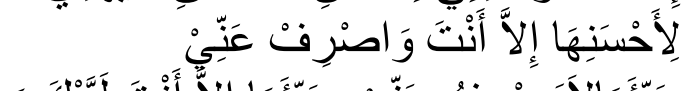

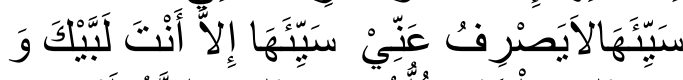

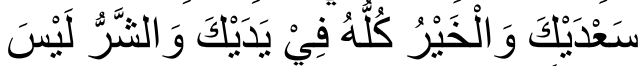

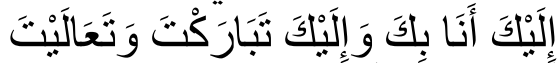

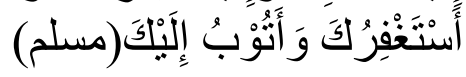

e. Membaca Surat Al-Fatihah.

Membaca surat al-fatihah secara tartil (jelas dan perlahan), Lalu Membaca salah satu surat di dalam Al Quran.

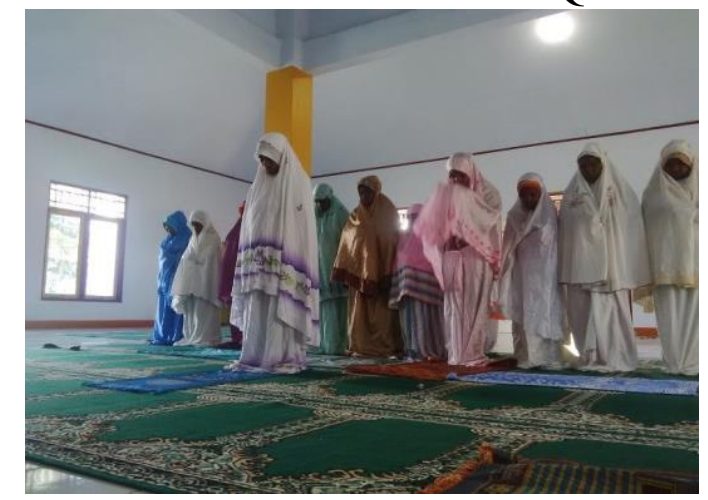

Gambar 2. Sholat Jamak dan Qashar

f. Ruku'

Mengangkat kedua tangan seperti Takbiratul Ihram sambil bertakbir : Allahu Akbar menuju posisi ruku'.Dasar hukumnya adalah AlQur'an Surat Al-Hajj ayat 77 :

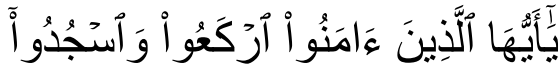
Wahai sekalian orang yang beriman! ruku' dan sujudlah kalian" (QS. Al-Hajj : 77). (Departemen Agama RI, 1982)

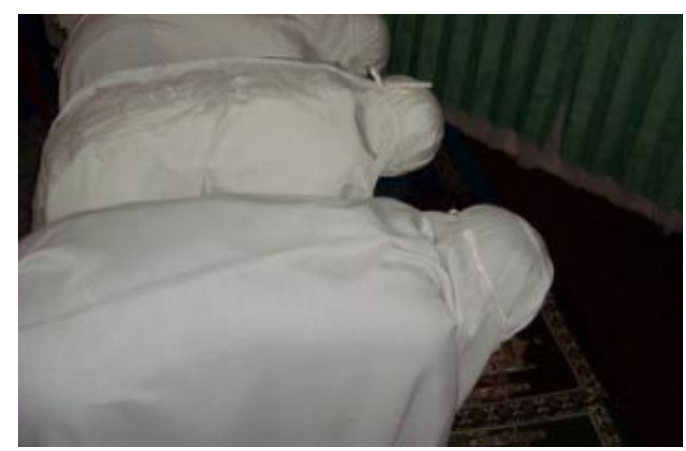

Gambar 3.Praktek Sholat Jamak dan Qashar

g. I'tidal

Setelah ruku'yakni berdiri tegak (I'tidal) dengan sempurna dan tenang. Hal ini didasarkan hadist Nabi saw, Dari Abu Hurairah:

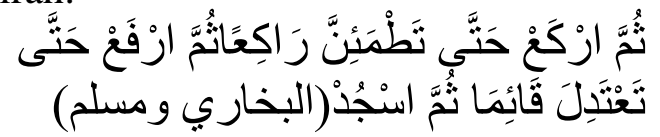

Kemudian ruku'lah hingga tenang, kemudian angkatlah kepalamu hingga tegak berdiri kemudian sujudlah.. (HR.Bukhari \& Muslim). (Compact Disc (CD).1999. Al Maktabah al-Syamilah)

h. Sujud

Bertakbirlah (اللُ اكبر) tanpa mengangkat tangan (HR.Bukhari \& Muslim), menuju gerakan sujud dengan meletakkan kedua lutut lebih dahulu lalu kedua tangan, kemudian meletakkan wajah (dahi dan hidung). Hadits dari Ibnu Abbas, Rasulullah saw bersabda:

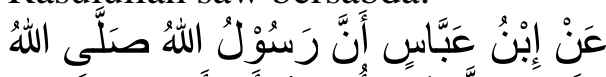

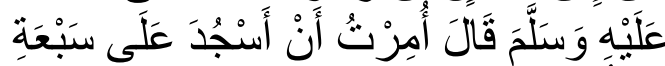

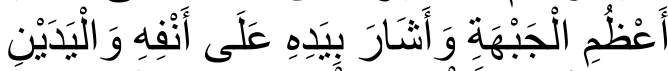

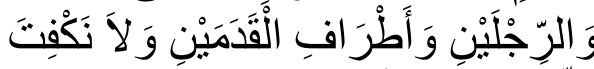

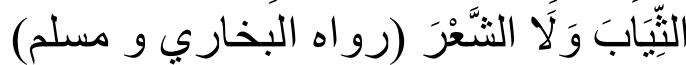

Dari Ibnu Abbas yang mengatakan bahwa Rasulullah saw bersabda: Aku diperintah supaya bersujud di atas tujuh tulang; dahi, seraya menunjuk pada hidungnya, diatas dua belah tangan, kedua lutut dan diatas kedua ujung kaki. 


\section{Ourralls}

(HR.Bukhari \& Muslim) (Compact Disc (CD).1999. Al Maktabah al-Syamilah)

i. Duduk tenang antara dua sujud

Setelah sujud kemudian bangkit sambil mengucapkan takbir (اللهُ اكبر) lalu duduk iftirasy (duduk di atas telapak kaki kiri, sedang kaki kanan : bertumpu dengan ujung jari-jarinya yang dilipat ke bawah), lalu membaca do'a :

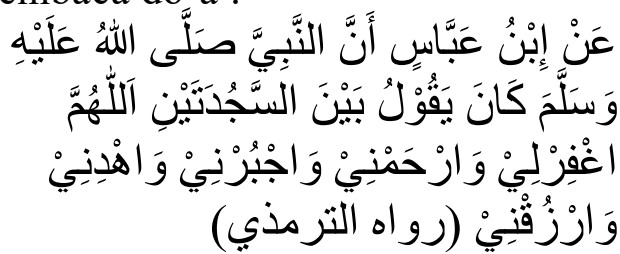

Menilik hadits Ibnu 'Abbas r.a. bahwa Nabi saw bersabda : di antara kedua sujud mengucapkan Allaahummaghfirlii warhamnii wajburnii wahdinii warzuqnii (HR.Tirmidzi)

j. Duduk Tasyahhud

Posisi duduk tasyahhud, posisi duduknya tawarruk yakni pangkal paha atas (pantat) yang kiri duduk bertumpu pada lantai sedangkan posisi kaki kanan sama dengan tasyahhud awal. Rasulullah saw bersabda :

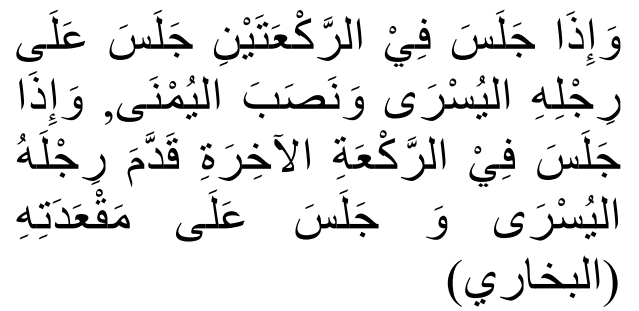

Dan apabila duduk pada rakaat kedua, beliau duduk di atas kaki kirinya dan menegakkan (telapak kaki) kanannya, dan apabila duduk pada rakaat yang terakhir, beliau memajukan kaki kirinya dan duduk bertumpu pada pantatnya. (HR.Bukhari). (Compact Disc (CD).1999. Al Maktabah al-Syamilah)

\section{k. Salam}

Setelah berdo'a dalam tasyahhud akhir, kemudian salamlah dengan berpaling ke kanan hingga terlihat pipimu dari belakang, Rasulullah saw bersabda :

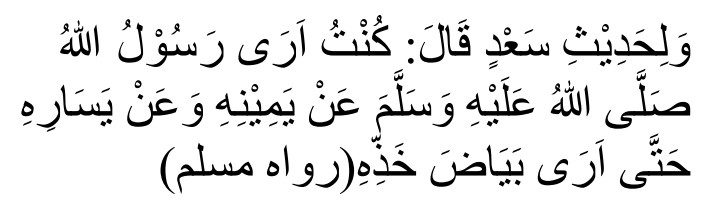

Dan hadits dari Sa'd: Saya melihat Rasulullah saw bersalam ke arah kanan dan ke arah kirinya, sampai kulihat putih pipinya. (HR.Muslim).(A.Razak, dkk.1984)

Dengan membaca: آلَسََّلَمُ عَلْيْكُمْ وَرَحْمَةُ اللَهِ وَبَرَكَاتُهُ

Lalu berpaling ke kiri hingga terlihat pipimu dari belakang dengan membaca:

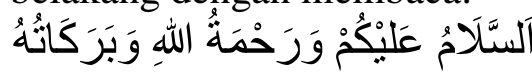

1. Kemudian Berdiri kembali

m. Diantara dua Shalat diselingi dengan Iqamat. Sebagaimana sabda Rasulullah saw:

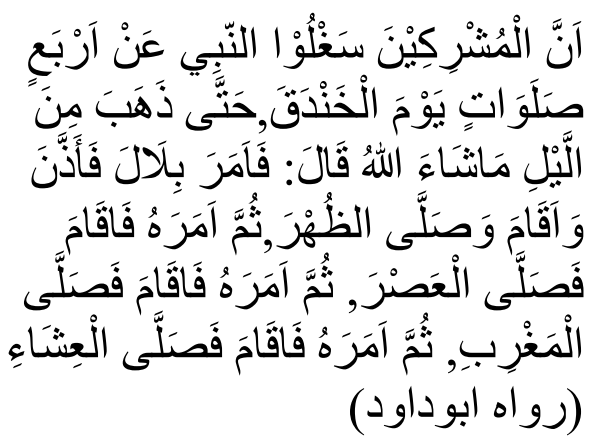

Bahwa kaum musyirik menganggu Nabi dari melakukan 4 Shalat, ketika pertempuran Khandak, hingga berlalu waktu malam yang hanya Allah saja yang tahu berapa lamanya. Cerita selanjutnya; maka Nabi pun menyuruh bilal menyerukan adzan dan iqamat, lalu ia shalat Zuhur, kemudian disuruhnya iqamat lagi dan ia pun shalat Ashar, kemudian disuruhnya lagi Iqamat dan ia pun shalat Magrib dan setelah itu disuruhnya pula Iqamat lalu shalay Isya' (HR.Abu Dawud).(Abu Dawud, t.t)

n. Dilanjutkan sholat berikutnya di awali iqomat lalu Takbiratul Ihram hingga salam.

\section{KESIMPULAN DAN SARAN}

\subsection{Kesimpulan}

Berdasarkan dari hasil pelatihan Sholat Jama' sesuai tuntunan Rasulullah saw di Majelis Taklim Rumpun An Nisa' 


\section{Ourrat:}

Kota Bengkulu, 95\% Anggota Majelis Taklim Rumpun An Nisa' Kota Bengkulu sudah mengetahui dalil dan Tata Cara melaksanakan Sholat Jamak dan Qashar yang sesuai dengan tuntunan Rasulullah SAW dan 5\% anggota majelis taklim sudah mengetahui tata caranya tetapi belum memahami dalilnya.

\subsection{Saran}

Sesuai dengan hasil kegiatan yang telah dilakukan, maka saran-saran dari kegiatan pengadian pada masyarakat ini adalah:

1. Diharapkan kepada Ibu-Ibu Anggota Majelis Taklim Rumpun An Nisa' dapat mensosialisasikan kepada keluarganya dan masyarakat secara umum di lingkungan Majelis Taklim Rumpun An Nisa' Kota Bengkulu.

2. Perlunya tindak lanjut mensosialisasikan tentang Sholat Jama' sesuai tuntunan Rasulullah SAW kepada pelajar dan remaja sebagai generasi penerus bangsa dan Agama.

\section{DAFTAR PUSTAKA}

A.Razak, dkk.1984. Terjemahan Hadits Shahih Muslim. Jakarta : Pustaka Al Husna.

Compact Disc (CD).1999. Al Maktabah alSyamilah.Versi 2.09 dan 2.11 (Memuat 20.000 Jilid dalam 6250 Kitab).Akses:http://www.shamela. ws

Dawud, Abu.t.t. Sulayman bin al-As'as alSijistani, Sunan Abi Dawud. CD.Mawsu at Al Hadits

Departemen Agama RI.1982.Al Quran dan Terjemahannya. Jakarta: Depag RI.

Jamaluddin, Syakir.2010.Kuliah Fiqih Ibadah. Yogyakarta : LPPI UMY.

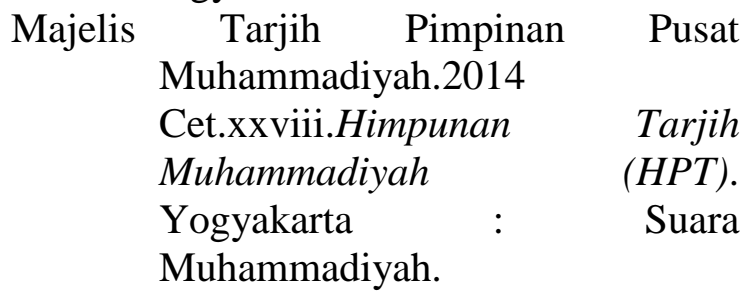

